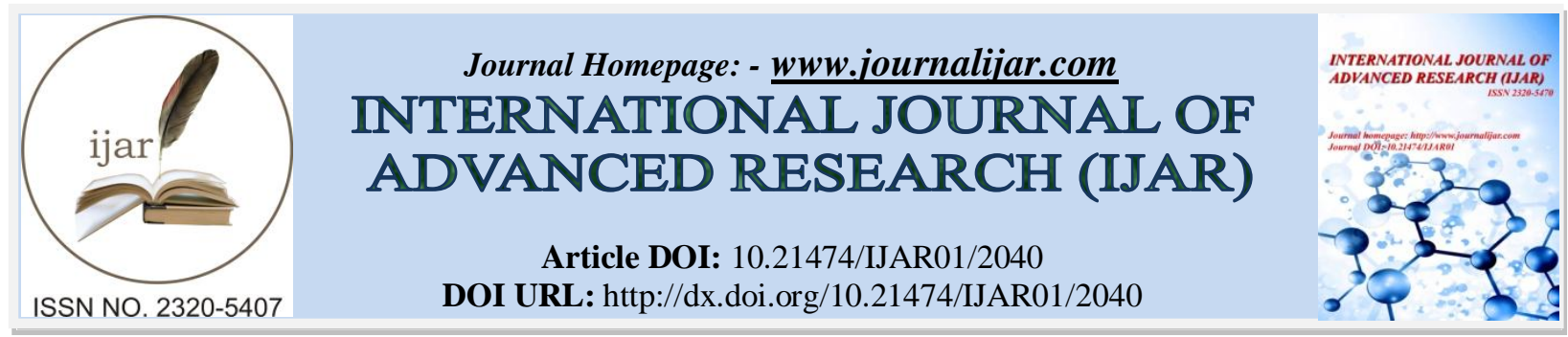

RESEARCH ARTICLE

\title{
"FORMULATION OF FRUIT ( GUAVA FRUIT JUICE)AND WHEY BASED BEVERAGES FLAVOURED WITH DIFFERENT HERBS USING NATURAL SWEETENER AS 'STEVIA'.
}

${ }^{*}$ Maya $^{1}$, Dube and Ritu $\mathbf{P}^{2}$.

1. Research Scholar, Dept.of Foods \& Nutrition Ethelind School of Home Science, Sam Higginbottom Institute of Agriculture, Technological and Sciences, (Deemed to be University) Allahabad-211007 (U.P.).

2. Assistant Professor. Dept.of Foods \& Nutrition Ethelind School of Home Science, Sam Higginbottom Institute of Agriculture, Technological and Sciences, (Deemed to be University) Allahabad-211007 (U.P.).

\section{Manuscript Info}

\section{Manuscript History}

Received: 29 September2016

Final Accepted: 15 October 2016

Published: October 2016

Key words:-

Whey based fruit herbal beverages.

\section{Abstract}

The environment in which we live, work and relax, is determining for our health and well being. Physical, as well as chemical and micro (biological) factors in the environment can have repercussions on our health, both physically and mentally. Whey is a nutritious by product from cheese, "chhana" and "paneer" industry containing valuable nutrients like lactose, protein, minerals and vitamins etc., which have indispensable value as human food. Whey protein is a mixture of globular proteins isolated from whey, the liquid material created as a by-product of cheese production. Fruits are important sources of vitamins and carbohydrates like fiber and sugar. They are low in calories and naturally sweet. Fruits and their juices are good sources of water, too and one of the finest body cleansers, cleaning morbid matter from the stomach, liver, kidneys, spleen, bladder, and is considered the finest, known colon cleanser. Herbs are small plants that have a fleshy or juicy stem when they are young. The leaves, stems, or seeds of herbs can be used fresh, or they can be dried for later use. Whey based herbal beverages provide the nutritional and healthy beverages for maintaining the health status and well-being. Storage of whey based beverages will enhance the quality, nutritive value, profitability, digestibility, acceptability and safety and overall increases the shelf- life of the products. The replication five time for all treatments and data obtained from investigation was statically analyzed by using analysis of variance ( ANOVA ) and critical difference ( CD) techniques. Sensory evaluation was carried out by using nine point hedonic scale.

The replication five time for all treatments and data obtained from investigation was statically analyzed by using analysis of variance (ANOVA) and critical difference (CD) techniques. Sensory evaluation was carried out by using nine point hedonic scale. In prepared herbal beverages, Treatment $\mathrm{T}_{3}(74 \%$ whey, $20 \mathrm{ml}$ Guava fruit juice, $6 \mathrm{ml}$ basil,

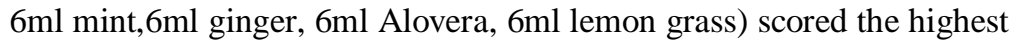
in all aspects in hedonic scale. Nutritional composition of $\mathrm{pH}$, TSS, Acidity, Total sugar, reducing sugar were increased significantly with 
increased in percentage of prepared beverages. Non reducing sugars, ascorbic acid, protein content in the prepared beverages were decreased.

Copy Right, IJAR, 2016,. All rights reserved.

\section{Introduction:-}

The environment in which we live, work and relax, is determining for our health and well being. Physical, as well as chemical and micro (biological) factors in the environment can have repercussions on our health, both physically and mentally.

A person's health is a very important aspect of his life - "health is wealth". For most human beings, staying fit and healthy is parallel to being wealthy, for a person's everyday life is influenced mainly by the state of his mind and body, especially by the presence and absence of certain diseases.

Beverages that contain sugars and other carbohydrates, proteins and/or fats also provide calories that, like the calories found in foods, contribute to an individual's total daily energy intake. As a result, it's important that beverage calories, like food calories, are managed as part of an individual's overall energy balance strategy to maintain a healthy weight. Fruit juices have been scientifically proven to give certain health benefits, provided that they are taken in moderation. Nutritionists also suggest that fruit juices should be taken in their pure state and people should only drink $100 \%$ fruit juice.

Freshly squeezed juices from fruits and vegetables are excellent sources of minerals and vitamins that catalyze chemical reactions occurring in the body. These enzymes also produce the energy needed for digestion, absorption, and conversion of food into body tissues. An increased intake of fruit and vegetable juices ensures that the body will efficiently absorb more minerals and vitamins.

Whey is a nutritious by product from cheese, "chhana" and "paneer" industry containing valuable nutrients like lactose, protein, minerals and vitamins etc., which have indispensable value as human food. It resulted in unraveling the secrets of why protein and other components and established a sound basis for their nutritional and functional value.

Fruits are important sources of vitamins and carbohydrates like fiber and sugar. They are low in calories and naturally sweet. Fruits and their juices are good sources of water, too. Different fruits contain different vitamins, so it is important to eat a variety of fruits. Mangoes, papayas, melons and citrus fruits, like oranges and grapefruit, are high in vitamin C. Cantaloupe, apricots, peaches, and nectarines are sources of vitamin A.

Herbs are small plants that have a fleshy or juicy stem when they are young. The stems of some herbs develop hard, woody tissue when they grow old. The leaves, stems, or seeds of herbs can be used fresh, or they can be dried for later use. Dried herbs can be pounded to a fine powder, placed in airtight containers, and then stored.

Whey based herbal beverages provide the nutritional and healthy beverages for maintaining the health status and well-being. Storage of whey based beverages will enhance the quality, nutritive value, profitability, digestibility, acceptability and safety and overall increases the shelf- life of the products.

\section{Materials And Methods:-}

The present investigation was Carried out in the Nutritional Research Laboratory Department of Foods and Nutrition, Ethelind School of Home Science, Sam Higginbottom Institute of Agriculture, Technology \& Sciences, (Deemed to-be University),(formerly Allahabad Agricultural Institute) Allahabad U.P.

* Five types of natural flavouring herbs (Basil, Mint, Ginger, lemon grass and alovera.) were used in formulation of whey based fruit herbal beverages. 
Development of whey based fruit herbal beverages.

Preparation of whey:-

The milk was heated in a stainless steel vessel to $84^{\circ} \mathrm{C}$. The hot milk will be acidified by adding citric acid (2\%) followed by continuous stirring resulting in complete coagulation of milk protein (casein). The liquid (whey) was filtered using a muslin cloth.

\section{* Preparation of guava juice}

Toke some guava in a trey, wash and cut guava fruit in small pieces and add in juicer. Extract the juice and store in a glass jar.

\section{* Preparation of herbs extract}

Herbs -Basil, Mint, Ginger, Lemon grass and Alovera was prepared from fresh leaves. The leaves will be washed, then blended in a mixer grinder and filtration will be done by muslin cloth.

\section{FLOW CHART FOR PREPARATION OF STANDARD WHEY BASED FRUITS HERBAL BEVERAGE}
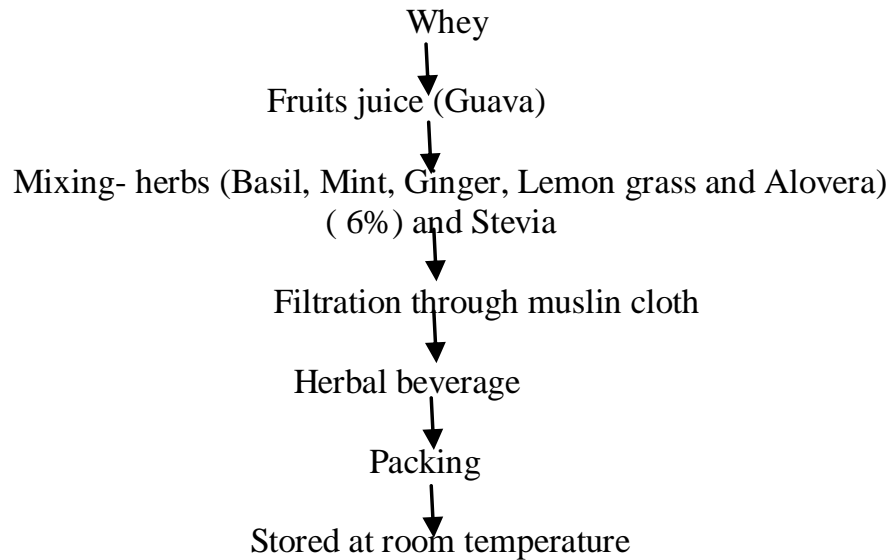

Source: Yadav et al, (2010) Development and storage studies on whey based banana herbal beverage. American journal of Food Technology, 5(2) pp 121-129.

\section{Results And Discussion:-}

The data of the present study on different aspect as per methodology was tabulated analyzed statistically. The result obtained from the analysis is presented and discussed in this chapter.

1. Physico- Chemical analysis of prepared beverages during storages of period.

2. Organoleptic characteristics of prepared beverages during storages of period.

3. Microbiological characteristics of prepared beverages during storages of period.

Physico-Chemical Analysis of Prepared Guava Fruit Juice and Whey Based Flavoured With Different Herbs

\begin{tabular}{|c|c|c|c|c|c|c|c|c|c|}
\hline \multirow[b]{2}{*}{ Component } & \multicolumn{9}{|c|}{ Treatments } \\
\hline & $\mathbf{T}_{0}$ & $\begin{array}{l}T_{1} \\
\text { (Basil) }\end{array}$ & $\begin{array}{l}\mathbf{T}_{2} \\
\left(\operatorname{Min} \mathbf{t}_{)}\right.\end{array}$ & $\begin{array}{l}\mathbf{T}_{3} \\
\text { (Ginger) }\end{array}$ & $\begin{array}{l}\mathbf{T}_{4} \\
\text { (Alovera) }\end{array}$ & $\begin{array}{l}\mathbf{T}_{5} \\
\text { (Lemon } \\
\text { grass) }\end{array}$ & F $5 \%$ & RESULT & $\begin{array}{l}\mathrm{CD}=\mathrm{SD}=+, \\
-\end{array}$ \\
\hline pH & 5.3 & 5.3 & 5.4 & 5.4 & 5.3 & 5.5 & 4.014 & $\mathrm{~S}$ & 0.041 \\
\hline TSS & 28.3 & 22.8 & 22.8 & 22.7 & 22.9 & 22.8 & 2617.32 & $\mathrm{~S}$ & 0.0621 \\
\hline Acidity & 0.43 & 0.43 & 0.44 & 0.44 & 0.43 & 0.44 & 0.5755 & NS & 0.0181 \\
\hline Total sugar & 11.04 & 11.19 & 11.92 & 12.10 & 11.81 & 11.57 & 105463.2 & $\mathrm{~S}$ & 0.0018 \\
\hline Reducing sugar & 6.93 & 6.45 & 6.69 & 6.65 & 6.48 & 6.55 & 3.5575 & $\mathrm{~S}$ & 0.0133 \\
\hline $\begin{array}{l}\text { Non-reducing } \\
\text { sugar }\end{array}$ & 4.10 & 4.73 & 5.22 & 5.44 & 5.32 & 5.01 & 33978.77 & $\mathrm{~S}$ & 0.012 \\
\hline Ascorbic acid & 11.42 & 12.50 & 13.32 & 11.72 & 11.55 & 11.57 & 77648.22 & $\mathrm{~S}$ & 0.0037 \\
\hline Protein & 0.55 & 0.74 & 0.78 & 0.66 & 0.99 & 0.58 & 3762.47 & $\mathrm{~S}$ & 0.0036 \\
\hline
\end{tabular}


Organoleptic Characteristics of Prepared guava and whey based herbal Beverages -

\begin{tabular}{|c|c|c|c|c|c|c|c|c|c|}
\hline \multirow{2}{*}{$\begin{array}{l}\text { Organoleptic } \\
\text { quality }\end{array}$} & \multicolumn{9}{|c|}{ Treatments } \\
\hline & $\mathbf{T}_{0}$ & $\begin{array}{l}\mathbf{T}_{1} \\
\text { (Basil) }\end{array}$ & $\begin{array}{l}\mathbf{T}_{\mathbf{2}} \\
\left(\operatorname{Min} \mathbf{t}_{)}\right.\end{array}$ & $\begin{array}{l}\mathbf{T}_{3} \\
\text { (Ginger) }\end{array}$ & $\begin{array}{l}\mathbf{T}_{4} \\
\text { (Alovera) }\end{array}$ & $\begin{array}{l}\mathbf{T}_{5} \\
\text { (Lemon } \\
\text { grass) }\end{array}$ & F $5 \%$ & RESULT & $\begin{array}{l}\mathrm{CD}=\mathrm{SD}=+, \\
-\end{array}$ \\
\hline Colour & 7.0 & 8.4 & 8.4 & 8.6 & 8.2 & 8.4 & 10.48 & $S$ & 0.046 \\
\hline Consistency & 6.4 & 8.0 & 8.2 & 8.4 & 8.0 & 8.0 & 46.65 & $\mathrm{~S}$ & 0.016 \\
\hline Flavour & 6.6 & 8.4 & 8.6 & 8.8 & 8.2 & 8.4 & 18.55 & $S$ & 0.048 \\
\hline Taste & 6.2 & 8.0 & 8.2 & 8.4 & 7.8 & 8.0 & 20.54 & $\mathrm{~S}$ & 0.043 \\
\hline $\begin{array}{l}\text { Overall } \\
\text { acceptability }\end{array}$ & 6.2 & 8.2 & 8.4 & 8.6 & 8.0 & 8.2 & 60.61 & $\mathbf{S}$ & 0.018 \\
\hline
\end{tabular}

Microbiological load in prepared Orange fruit juice and whey based beverages flavoured with different herbs on different storage of period.

\begin{tabular}{|c|c|c|c|c|c|c|c|c|c|c|c|c|}
\hline & \multicolumn{2}{|c|}{ DAY } & \multicolumn{2}{|c|}{ DAYS } & \multicolumn{2}{|c|}{ DAYS } & \multicolumn{2}{|c|}{ DAYS } & \multicolumn{2}{|c|}{ DATS } & \multicolumn{2}{|c|}{ DAYS } \\
\hline & B & Y\&M & $\mathbf{B}$ & Y\&M & B & Y\&M & B & Y\&M & B & Y\&M & B & Y\&M \\
\hline $\mathbf{T}_{\mathbf{0}}$ & - & - & - & - & - & - & - & - & - & - & 5 & 2 \\
\hline $\mathrm{T}_{1}$ (Basil) & - & - & - & - & - & - & - & - & - & - & 5 & 2 \\
\hline$T_{2}$ (Mint) & - & - & - & - & - & - & - & - & - & - & 3 & 2 \\
\hline $\mathbf{T}_{3}$ (Ginger) & - & - & - & - & - & - & - & - & - & - & 3 & 2 \\
\hline $\mathbf{T}_{4}$ (Alovera) & - & - & - & - & - & - & - & - & - & - & 4 & 2 \\
\hline$T_{5}$ (Lemon grass) & - & - & - & - & - & - & - & - & - & - & 2 & 1 \\
\hline
\end{tabular}

\section{Conclusion:-}

From the result summarized, it is concluded that "Formulation of Fruit (Guava Fruit Juice) And Whey Based Beverages Flavoured with Different Herbs Using Natural Sweetener As 'Stevia' The prepared beverages were well accepted with regards to, sensory characteristics. In prepared of herbal beverages, Treatment $\mathrm{T}_{3}(74 \%$ whey, $20 \mathrm{ml}$ guava fruit and $6 \mathrm{ml}$ basil, $6 \mathrm{ml}$ mint, $6 \mathrm{ml}$ ginger, $6 \mathrm{ml}$ Alovera, $6 \mathrm{ml}$ lemon grass) scored the highest in all aspects in hedonic scale. Nutritional composition of pH, TSS, Acidity, Total sugar, reducing sugar were increased significantly with increased in percentage of prepared beverages. Non reducing sugars, ascorbic acid, protein content in the prepared beverages were decreased.

\section{Recommendation:-}

Intake of "Formulation of whey based fruit herbal beverages using natural sweetener 'Stevia" beverages is recommended in normal diet as it will help in relieving stress and contribute as an anti-diarrheal agent. It possesses significant therapeutic properties like anti-microbial, anti-inflammatory. Due to incorporation of the fruits and herbs extract in whey, the medicinal value of the beverages increases. Its high nutrient content in the beverages will act as free radical scavengers which purify and detoxify the body and will keep diseases at bay.

\section{LITERATURE CITED:-}

1. Abigail K., (2005) Spices and type two diabetics, Journal of Nutrition and Food Science 35 (2):pp 81-87.

2. Admin (2007) Indian herbs like Tulsi and Pudina can help to prevent cancer under cancer treatment of Herbs of Nutrition and Food Science pp: 50-56.

3. Agarwal, P. and Das, S. (2000) Indigenous milk production in India. Indian Dairyman, of Nutrition and Food Science 42 (2): 61-74.

4. American Institute for cancer research (2013) an article on "Road that fight cancer." www.aicr.org. 
5. Anreey (2007) "Medicinal uses of carrots". Florida Cooperative Extension Services. Institute of Agricultural Sciences, University of Florida. Magazine for Food Technologist. (9):87-88.

6. AOAC (2005) Official method of analysis. $18^{\text {th }}$ edition. Association of Official Analytical Chemists, Washington, D.C.

7. Baljeet S.Y. Ritika B. Y., and Sarita, R., (2013) "Studies on development and storage of whey based pineapple (Ananas Comosus) and bottle gourd (lagenaria Siceraria) mixed herbal beverages. International Food Research Journal 20(2): 607-612(2013)

8. Barhurst K., (2006) The health benefits of Herbs and Spices-the past, the present and the future Medical Journal of Australia, 185:4-21.

9. Bryer E., (2005) A Literature review of effecteness of ginger in alleviating mild-to-moderate nausea and vomiting of pregnancy Journal of Mid- wifery women's Health. 50 (1) : 1-3.

10. Body felt and W., Floyd (2005) Dairy product cards: are They consistent with principles of sensory evaluation American Dairy Science Association., 94:392- 398.

11. Bandyopadhyay R.S. (2006) A study of formulators' and process techniques of special Indian foods process Techniques of special Indian foods traditional sweets and herbal sweets Indian Dairyman, 56 (5) : 23-35.

12. Chen Hu-Yin and Gow-Chin Yen (2006) Antioxidant activity and free radical scavenging capacity of extracts from guava (psidium guava L) leaves, Journal of Food Chemistry 54 (5) : 692- 693.

13. Cavazos H (2010) Health benefits of amla juice. Article from The Livestrong Foundation. 6(4):44-52.

14. Coffman, M., (2013) Health benefits of citrus beverages. Journal of Health and Nutrition. 15(3): 124-131. 